\title{
Formation of Digital Competences of University Library Users
}

\author{
Ruslan A. Baryshev, Elena N. Kasyanchuk, \\ Irina A. Tsvetochkina and Olga I. Babina" \\ Siberian Federal University \\ Krasnoyarsk, Russian Federation
}

Received 22.05.2021, received in revised form 04.06.2021, accepted 06.07.2021

\begin{abstract}
The paper presents various approaches to defining the concepts of 'information competencies' and 'digital competencies'. The point of view of scientists on the essence, structure and ways of developing digital competencies are considered, the concept of students' digital competence in modern conditions is clarified. The influence of this process on the development of the university library is emphasized. Digital competence is defined as the student's high-level ability to communicate in the digital space (highly mobile intelligent devices, smart technologies, network professional communities) with the goal of self-realization and continuous innovative development.

Among new challenges for the university library in digital environment the main ones are considered to be the emergence of new social and technological tasks, the specifics of working with users of the university library, and changing access to electronic resources while maintaining the invariability of main functional purpose of university library. The integrity and systemic development of digital competence of students in the conditions of the university library is reflected. The purpose of this paper is to unlock the potential of the university library as a subject of digital competencies development of students who will work in the digital age.

The experience of the Scientific Library of the Siberian Federal University on developing digital competence of students is presented. Profiles of digital competencies of library users are proposed, which include two areas of responsibility: 1) information competencies and 2) digital competencies. The results of the study were refined and summarized, the results of the study were systematized, methodological recommendations were prepared to increase the effectiveness of libraries.
\end{abstract}

Keywords: competency approach, digital competencies, digital culture, information competence, digital literacy, digital services, university library, electronic library, user training.

Research area: culturology.

(C) Siberian Federal University. All rights reserved

* Corresponding author E-mail address: babina62@yandex.ru ORCID: 0000-0002-4383-2830 (Baryshev); 0000-0002-8568-6042 (Kasyanchuk); 0000-0001-6138-8983 (Tsvetochkina); 0000-0002-9909-3205 (Babina) 
Citation: Baryshev, R.A., Kasyanchuk, E.N, Tsvetochkina, I.A., Babina, O.I. (2021). Formation of digital competences of university library users. J. Sib. Fed. Univ. Humanit. Soc. Sci., 14(9), 1420-1431. DOI: $10.17516 / 1997-1370-0792$.

\title{
Формирование цифровых компетенций пользователей университетской библиотеки
}

\author{
P.А. Барышев, Е.Н. Касянчук, \\ И.А. Цветочкина, О.И. Бабина \\ Сибирский федеральный университет \\ Российская Федерация, Красноярск
}

\begin{abstract}
Аннотация. Представлены различные подходы к определению понятий «информационные компетенции» и «цифровые компетенции». Рассмотрена точка зрения ученых на сущность, структуру и пути развития цифровых компетенций, уточнено понятие цифровой компетентности студентов в современных условиях. Подчеркнуто влияние этого процесса на развитие университетской библиотеки. Цифровая компетентность определена как способность студента высокого уровня общаться в цифровом пространстве (высокомобильные интеллектуальные устройства, интеллектуальные технологии, сетевые профессиональные сообщества) с целью самореализации и непрерывного инновационного развития.

Новыми вызовами для университетской библиотеки в цифровой среде считают появление современных социальных и технологических задач, специфику работы с пользователями, изменение доступа к электронным ресурсам при сохранении неизменности основного функционального назначения. Отражена целостность и системность развития цифровой компетентности студентов. Цель данной статьи раскрыть потенциал университетской библиотеки как субъекта развития компетенций студентов, которые будут работать в цифровую эпоху.

Представлен опыт Научной библиотеки Сибирского федерального университета по развитию цифровой компетентности студентов. Предложены профили компетенций пользователей библиотеки, которые включают две области ответственности: 1) информационные компетенции и 2) цифровые компетенции. Результаты исследования были уточнены, обобщены и систематизированы, подготовлены методические рекомендации по повышению эффективности работы библиотек.
\end{abstract}

Ключевые слова: компетентностный подход, цифровые компетенции, цифровая культура, информационная компетентность, цифровая грамотность, цифровые услуги, университетская библиотека, электронная библиотека, обучение пользователей.

Научная специальность: 24.00.00 - культурология.

\section{Introduction}

The rapid growth of digital technologies has a significant impact on the development of the economy and society. The role of individual technologies, such as artificial intelligence, the Internet of things and blockchain, is increasing, what leads not only to the transformation of production processes, but also to the emergence of 
new markets, a radical change in business models (platforms, ecosystem companies etc.) (Hallo et al. (2016)). Decisions based on digital technologies give opportunity to optimize processes, simplify scientific and technological cooperation, promote the connectivity of territories, and involve small enterprises in value chains. The key resources of the digital economy are intangible assets (information, knowledge, competencies) (Abdrakhmanova et al. (2020).

One of the main conditions for the development of digital technologies and their implementation into practical activities is the process of formation and development of digital competencies. The study of digital competencies problems in Russia was actively promoted after the adoption of the national program 'Digital Economy of Russian Federation' in 2018. Russian Federation Ministry of Digital Development, Communications and Mass Communications has been appointed the responsible executor of the national project 'Digital Economy'. On December 24, 2018, the Passport of the national program 'Digital Economy of the Russian Federation' was approved, the Passport provides the long-term (until 2024) implementation of the following federal projects: normative regulation of the digital environment, information infrastructure, personnel for the digital economy, information security, digital technologies, digital public administration.

According to the Federal Project 'Personnel for the Digital Economy', the concept of the basic model of the digital economy competencies, a list of key competencies and updating mechanism of these competencies should be developed. In February of 2019, the Analytical Center under the Government of the Russian Federation held a round table on 'Discussion of approaches to the formation and implementation of the basic model of the digital economy competencies'. The developed model will be created in advance, it will be integrated into different levels of education. Professional standards will be taken into account, and digital competencies will be reflected in federal state educational standards.

However, currently there is no unambiguous method of digitalization process. All the definitions of the digital economy that are found in the literature describe digital economy as «economy created on a new technological basis» and «economy multiplied by new technological capabilities, primarily the ability to collect, store and transfer huge amounts of data».

Global technological advances are forcing organizations to digitize their resources and functions. This process is becoming more intense. Digital tools provide a variety of possibilities to manage changes. They help employees of the organization communicate globally and in a new way. The problem of people being ready for existence and development in the digital environment has become relevant. However, these tools still are not publicly available in modern organizations not only in Russia (Kohnke (2017), Astakhova (2019), but also abroad (Dempsey (2017), Ducas (2020), Khan (2017), Pontika (2019).

The process of digitalization is also underway in the field of higher education. Educational institutions are equipped with high-quality software, information systems presenting access to educational resources, electronic scientific libraries, the results of modern scientific research and development. In these circumstances, the problem of the active use of digital resources in accordance with the goals and objectives of modern education is relevant. To solve this problem, it is necessary to form training competencies that they will need in the conditions of digital economy development.

The purpose of this paper is to unlock the potential of the university library as a subject of digital competencies development of students who will work in the digital age.

\section{Digital transformation of education}

The rapid development of the digital economy in Russia requires the system of higher professional education to train specialists who can easily adapt to the quickly changing conditions of the professional environment, to the fast perception and processing of large amounts of information, to master modern tools, methods and technologies of work (Cox et al. (2019).

Digitalization of the economy affects the life of the people and the functioning of the labor market. The demand for labor is also trans- 
forming under the influence of digital technologies: the need for specialists in the field of information and communication technologies is increasing, and skills in working with these technologies are becoming mandatory for many professional groups. Digital skills determine the competitiveness of an individual in the labor market: the number and quality of jobs available to him, the level of wages. And the prevalence of such skills affects the level of development and competitiveness of the country's economy (Abdrakhmanova et al. (2020).

According to the National Doctrine of Education in the Russian Federation until 2025, the education system is designed to provide training for highly qualified specialists capable of professional growth and professional mobility in the conditions of society digitalization and the development of new knowledge-intensive technologies, which is impossible without their developed ability to implement complicated information activities.

The reform of higher vocational education on the basis of a competent approach and its use in assessing the quality of future specialists' training has updated the study of problems related to the definition of ways to form competencies, not individual knowledge and skills. In accordance with the Federal State Educational Standards for Higher Professional Education, which are based on a competent approach, graduates of all educational areas must have general cultural and professional competencies, related to information processes in one way or another. Despite the fact that information education in universities is actively developing, employers still point to a low level of knowledge of graduates of information work technologies, their information and analytical thinking (Smolina (2016).

The wide and intensive development of computer educational programs, primarily online ones, radically changes the process and format of higher education and is a serious challenge to higher school - both in the content of the educational process and in its organization. Digitalization requires new, completely different competencies. The main function of learning and education is to «teach to learn", to be ready for changes, to work with more com- plex projects, to borrow advanced practices including foreign ones, to expand the outlook by tracking trends in other industries and professions (Adeleke et al. (2019), Green et al. (2017). Moreover, the digital competence of university graduates should exceed the existing nomenclature of competencies - in order to work ahead of the situation. Digital technologies radically change the content of taught disciplines and the form of their submission. Universities are actively entering the mass education market of the already established international form of distance education with open Internet access (Tulchinsky (2017).

\section{Competence and digital competencies}

Modern imperatives of mastering new digital technologies have actualized the problems of digital literacy and digital culture. Emergence and wide circulation of the competencebased approach to education which united in itself knowledge, abilities, possession and personal qualities of the person led to emergence of the new term - information competences which is smoothly transformed to digital competences today. The term digital competencies today is the most common in the West (Praseptiawan et al. (2019), Raza et al. (2019), Shen (2019), Sinisalo (2015), Soltovets et al. (2020) but not in Russia (Astakhova (2019).

There is no consensus on the concept and structure of digital competence in pedagogical science. We will determine the concepts of information and digital competence, which are an instrument for the development of the information and digital culture of an individual.

Information culture of personality includes information worldview, value aspects and is characterized by integration into the sphere of culture. Since information can exist in different forms, including digital, it is logical to assume that digital culture is part of information culture (Astakhova (2019). To seize information culture it is necessary to have information competences (knowledge, abilities, skills).

The concept of information competence is quite broad. N.I. Gendina analyzed various definitions related to the concept of information culture, and came to the conclusion: at 
present «non-unified terminology is used, which often does not have a clear definition... instead of such simple for some people concepts defining a person's knowledge and skills in such work with information, as... 'computer literacy', 'information literacy', 'information culture' (Gendina (2005). T. S. Vinogradova imagines information competence as "personality quality, which is a combination of knowledge, skills and value attitude to the effective implementation of various types of information activities and the use of new information technologies to solve socially significant problems that arise in real situations of a person's daily life in society» (Vinogradova (2012), Smolina et al. (2019).

Tabachuk N.P. defines information competence as an integral characteristic related to the experience in information reality, methods of interaction with technology and technology in order to realize the general and professional information needs of a person (Tabachuk (2019).

Thus, information competence is an integrative quality of a person, which is the result of interpretating the processes of selection, absorption, processing, transformation and generation of information into a special type of subject-specific knowledge, which allows you to develop, make, predict and implement optimal decisions in various areas of activity.

Digital culture is a set of competencies that characterize the ability to use information technologies and communication technologies for a comfortable life in a digital environment, to interact with society and solve digital problems in professional activities (Mikhailova et al. (2019).

Astakhova L. V. defines the digital competence of a person as their high-level ability for information interaction in the digital space of highly mobile intelligent devices, smart technologies and network professional communities with the goal of self-realization and continuous innovative development (Astakhova (2019).

Tabachuk N.P. defines digital competence as high-level meta-abilities for the existence in digital space of highly mobile intelligent devices; SMART-competence as a formation of
SMART-person's personality, which perfectly utilizes SMART-technologies for search, analysis of information and creation of innovations, and interacts in professional network communities (Mikhailova et al. (2019).

The European system of digital competencies for citizens, known as DigComp 2.0, includes 5 areas of digital competencies (Astakhova (2019): 1. Information literacy. 2. Communication and cooperation. 3. Creation of digital content. 4. Safety. 5. Problem solving.

Competencies of digital culture can be divided into universal, general professional and professional competencies. The universal competencies of students' digital culture meet the social and personal needs of harmonious personal development and socialization in the information society based on the use of invariant technology for the collection, processing and interpretation of data arrays in digital form and are common to all areas of training of relevant levels of higher education.

The general professional competencies of digital culture characterize the ability of a graduate to use subject-independent technologies for collecting, processing and interpreting content-invariant data arrays in digital form (Baker et al. (2016), Chalkiadaki (2018), Grant et al. (2020).

Professional competencies of digital culture characterize the ability of a graduate to use subject-oriented technologies for collecting, processing and interpreting object-oriented data on the tasks of professional activity and the content of data arrays in digital form. The basic (key) competencies of digital culture, which include universal and general professional competencies, are common (mandatory) for various profiles of university training (Mikhailova et al. (2019)).

\section{Role of the university library in the formation of digital competencies}

The university library has always made great efforts to develop information education in the country as an information and educational center of the university. The library of the university is traditionally engaged in the collection, cataloguing and promotion of the library fund, systematic study of the informa- 
tion needs of users, raising the level of library's bibliographic and information knowledge, and popularization of services. With the development of information technologies, there was a need for training in the search for information on the Internet, work with scientific databases and licensed electronic resources (Kudrina et al. (2019).

The formation of competencies that allow you to not only search for information, but also critically evaluate it, protect yourself from harmful effects in the media space, create new content, distribute information through various channels come to the fore. Any specialist's success in professional activity in the conditions of informatization of society will depend on the ability to function in the 'information field' (Smolina et al. (2019).

The range of digital competencies as an object of teaching students by the university library may include their ability (Chalkiadaki (2018), Soria et al. (2017), Wadson (2019), Wadson (2019), Zaitseva et al. (2017).

): 1) to consume digital content: its search, selection, understanding, evaluation, interpretation, storage, protection; 2) reproductive activity in the digital environment: interaction and cooperation, interchange of digital content based on network etiquette standards; 3) productive activities in the digital environment: creation, integration and creative processing of digital content, including processing that uses programming and machine learning technologies, copyright protection; 4) reflexive activities in the digital environment: identifying information and digital needs and gaps in digital competence for the implementation of various activities in this environment (consuming, reproductive and productive). We believe that modern Russian university libraries can focus on expanding the range of competencies related to these aspects of user information behavior in the digital environment.

The forms of information competence libraries users training are diverse. Its content is to teach to use the library resources both on material and electronic media, remotely; develop search skills on the Internet, in the database and electronic catalog of the library; information quality assessment etc. The choice of the training form depends on the goals of the university library, the level of trainees' information culture and the librarians' style of work (Smolina et al. (2019).

In a digital society, forms of learning must inevitably change: traditional library lessons into a mixed learning, i. e. combined with video instructions, hypertext and interactive textbooks, specially developed web pages etc. For successful development of students' digital competencies in explained earlier limits including use of innovative forms and methods university libraries require closer integration at all levels: with the university management, faculty, students, employers etc. (Astakhova (2019).

Training in digital competencies by the university library has to be integrated into the curricula and plans of all levels of education, including graduate school. One of the principles of this process is continuity: the library can actively cooperate with employers to develop the digital competencies of current and future employees of organizations.

\section{Materials and methods \\ Stages of the study}

Siberian Federal University (SibFU) is a leading university, driver of economic development of the East Siberian region. SibFU is multidisciplinary higher educational institution conducting educational activities in 41 main educational programs. Some of its tasks are the digitalization of educational and research processes, increasing the level of digital literacy, developing competencies for the digital transformation of education.

The scientific library of the SibFU (SL SibFU) as one of the divisions of the university provides information support for the educational process and scientific research. Students make up to $90 \%$ of the total number of users, respectively, the key task of the library is to promote the educational, scientific and professional activities of students.

A significant part of library processes has been put into digital mode. An extensive fund of electronic information resources has been formed (today about 60 million documents are available to users); A document search system 
has been set up. There are various services for readers: users are registered in an automated mode; order and reception of literature, electronic copies of documents on inter-library subscription. Users are informed about new sources of information in accordance with individual thematic requests. Library employees conduct training on working with information databases, library services, bibliographic managers etc. The electronic course «Digital information resources for research and educational activities» has been developed. Online seminars are regularly held on the preparation of scientific articles for publication in highly rated foreign publications with the involvement of leading scientists of the SibFU.

To determine the effectiveness of training events, study and analyze the digital competencies of library users, identify possible problems and form an information promotion strategy, a study was conducted to determine the digital competencies of users.

All the work carried out within the framework of this study can be divided into three main stages.

At the first stage, a detailed analysis of scientific sources was carried out, on the basis of which it was possible to identify existing approaches to the definition of the concepts of 'information competencies' and 'digital competencies'.

At the second stage, the state of the problem of developing the digital competence of students in domestic and foreign science and the practice of higher educational institutions was analyzed, the concept of developing the digital competence of students in modern conditions is clarified. The influence of this process on the development of the university library in the conditions of digitalization is emphasized.

At the third stage, experimental work was carried out to develop the digital competencies of students at the university. Profiles of digital competencies of SL SibFU users are proposed, which include two areas of user responsibility: 1) information competencies and 2) digital competencies. The results of the study were refined, summarized and systematized, methodological recommendations were prepared. The study identified students' priorities in the use of electronic resources. The results of the study make it possible to develop a Library Development Strategy and identify measures to increase the effectiveness of the library.

\section{Experimental study base}

The scientific library of the Siberian Federal University is the experimental base of this study.

\section{Analysis of digital skills of students of SFU}

The sociological study «Digital competencies of SL SibFU users» was organized in order to analyze the digital competencies of library users. It should help to adjust the work of the library to train users, satisfy their needs and requests as much as possible, improve the comfort of service.

The method of collecting information was a survey (questionnaire) was conducted in electronic form. The questionnaire was anonymous. Google tools were used during data processing. The questionnaire consisted of 13 questions, which provided a multivariable way of answering (one question was open and suggested a detailed answer). Answers for some questions used the method of users' selfassessment of their digital competencies level.

Students of 15 university institutes took part in the questionnaire. A total of 948 respondents were interviewed.

Research hypothesis: users of the Scientific Library have a sufficient level of digital competence related to the search for information and work with electronic information resources and services, as well as high digital skills that allow them to work effectively in a digital environment.

The questions were grouped into clusters and presented in table 1 :

1. Information competencies in digital environment.

2. Digital competencies.

\section{Analysis of study results}

The first set of questions showed that about $79 \%$ of respondents have a level of knowledge of information technologies sufficient for educational activities that allow them to search the Internet and the library. When answering the 
Table 1. Grouping Questionnaire Questions by Block

\begin{tabular}{|c|l|}
\hline Type & \multicolumn{1}{|c|}{ Questions } \\
\hline $\begin{array}{c}\text { Information } \\
\text { Competencies }\end{array}$ & $\begin{array}{l}\text { Rate the overall level of digital technology proficiency of university students. } \\
\text { Are you having difficulties finding information for training? } \\
\text { What information resources are the most convenient for you? } \\
\text { What educational resources do you use the most for preparation to classes? } \\
\text { How often do you use the electronic catalog of the Scientific Library to search for information? } \\
\text { Which forms of digital resource training do you think are most effective? } \\
\text { Competencies } \\
\text { Are you part of the online communities of the Scientific Library of the SibFU on social net- } \\
\text { works? }\end{array}$ \\
$\begin{array}{l}\text { What digital services and/or computer programs do you use in training the most? } \\
\text { Which of the Russian scientific and educational databases that are subscribed to by the Sci- } \\
\text { entific Library of the SibFU have you worked with? } \\
\text { Which of the foreign databases that are subscribed to by the Scientific Library of the SibFU } \\
\text { have you worked with? } \\
\text { What digital services of the Scientific Library do you use? } \\
\text { What new digital services, in your opinion, should be implemented in the Scientific Library } \\
\text { of the SibFU? }\end{array}$ \\
\hline
\end{tabular}

question: "Which information resources are the most convenient for you?» the vast majority of library users ( $93 \%$ ) chose electronic resources. To prepare to classes, most users more often use various search engines (34.9\%), educational portals and sites (27\%), to a lesser extent - digital educational resources and electronic libraries $(7.9 \%)$, open electronic scientific resources (Open Access - $7.9 \%$ ), resources of the Scientific Library of the SibFU $(6.3 \%)$.

The educational and scientific activities of the modern user of the library can not be imagined without the use of modern means of communication: e-mail, messengers and social networks. Today social networks are the most convenient platform for informing about library's resources, services and events, a way of interaction between the librarian and the user, and a means of promoting library services. The vast majority of users surveyed are subscribed to the online communities of the Scientific Library on social networks (63\% on Vkontakte and $37 \%$ on Instagram and Facebook).

The results of this response block revealed a low demand among students for library information resources compared to open sources on the Internet, setting for librarians the task of more active promotion of their electronic col- lections, for example, through social networks, since students are active users of these communication sites.

The next block of questions is devoted to the analysis of the overall level of digital literacy of users and the use of digital technologies in educational and scientific activities.

The question «What digital services and/ or computer programs do you use in training the most?» showed that $82.5 \%$ of respondents use office applications and programs the most to prepare and demonstrate presentations and video materials $(76.2 \%)$, as well as specialized software (MathCAD, AutoCAD, ANSYS, etc.) $-20.6 \%$, since ownership of these software products is necessary for successful completion of educational disciplines.

One of the key issues was the most preferred services among library users in distance learning (see Figure 1).

The results showed that the services of the SFU: My SFU, E-courses, Webinar SFU - are actively used by students, which means they will be effective for integrating library resources into the university's information environment.

To determine how to interact with users, the question was asked: «Which forms of training when working with digital resources 


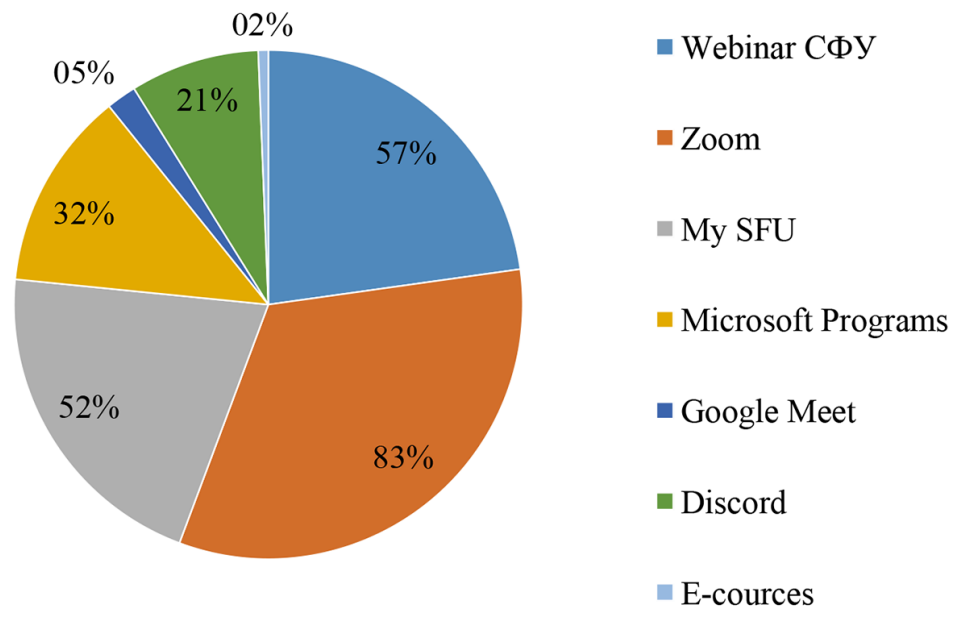

Fig. 1. The most convenient services for users in digital learning

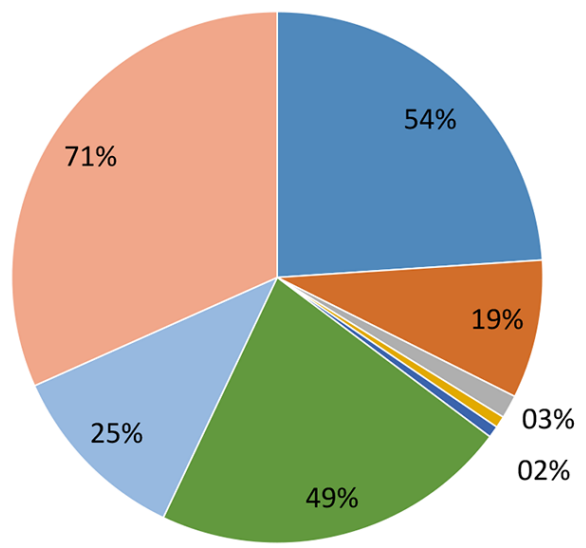

- Elibrary

- Znanium

IPR books

Lan'

n Dissertations of the Russian State

Library

- Archive of electronic resources

of the SFU

$\square$ SFU Electronic Library

$02 \%$

Fig. 2. Use of Russian electronic resources

are the most effective?». The vast majority of respondents $(82.5 \%)$ expressed a desire to take part in e-learning courses, $34.9 \%$ noted individual online consultations and $30.2 \%-$ individual offline consultations, $14.9 \%$ would like to undergo training in working with information resources and only $7.9 \%$ of students voted for inclusion in the curriculum of the discipline «Fundamentals of information culture».

The active use of Russian information resources is shown in Figure 2. The most popular among students is the electronic library of the SFU (71.4 \%). Among Russian databases, students prefer eLIBRARY.RU, the largest Russian information portal containing more than 13 million abstracts and complete texts of publications. This resource is used by $54 \%$ of respondents; 49,2\% of respondents in their activities include the Litres.ru resource, containing popular scientific literature and fiction. A low percentage (about $4 \%$ or less) of turns was noted to the dissertation database of the Russian State Library and electronic library systems.

An analysis of the use of foreign electronic resources showed that less than $20 \%$ of respondents turn to these resources. The main reasons for the low use of foreign databases are the lack of knowledge of the foreign language and the inactive participation of students in research activities. 
To the question: «What digital services of the Scientific Library do you use?» respondents answered as follows: online registration in the library $(38,1 \%)$, viewing the electronic form $(27 \%)$, booking publications $(7.9 \%)$, replacing of lost books (1.6\%), determination indices $(6.3 \%)$, inter-library subscription (3.2\%), book security (4.8\%), text checking for borrowing (76.2 \%), room booking (3.2\%), online-registration to return books $(6,3 \%)$, Directory assistance (7,9\%). The answers showed that possessing digital competencies, students are inactive in using the resources and services offered by the SL SibFU.

It can be assumed that students do not have enough information (what resources are available in libraries) and skills to work with library resources. Therefore, librarians need to review the needs of users and plan activities to improve performance. However, while answering the question «What new digital services need to be implemented in the Scientific Library of the SibFU?» most readers $(78 \%)$ answered that the library is fine as it is. Only a quarter of respondents offered their options: $22 \%$ indicated that they wanted to receive video consultations and to have access to advanced training courses with a certificate for its completion, as well as access to the Coursera platform and a reading app for mobile devices.

Analyzing the results, it can be noted that the hypothesis about the high level of digital competencies of library users has been confirmed. Most users confidently use basic Internet technologies, students prefer open sources in the Internet to the information resources of the Scientific Library, they have developed stable communication skills for work in a digital environment.

As a result of the study, the objectives of the Scientific Library were clearly identified:

1. Creating digital products in various formats about the resources and services of the Scientific Library.
2. Formation of competencies among students on qualified search of information in library resources, assessment of quality of received information, competent use of it, compliance with academic ethics standards in digital environment.

3. Integration into the university's information environment through the use of digital services of the SibFU for the promotion and conduct of training events.

4. Use library and university online communities as a communication platform.

5. Further development of its own digital user consulting services.

\section{Conclusion}

Digital technologies radically change the content of taught disciplines and the form of their submission. The reform of higher professional education on the basis of a competent approach and its use in assessing the quality of training of future specialists made the study of problems related to the definition of ways to form digital competencies that ensure the solution of information problems a relevant issue.

The challenges of the university library from the digital environment, while maintaining the invariability of its main traditional functional purpose, radically change many technologies and forms of its work. New technological tasks are emerging, access to information resources is changing, ways of working with users are being transformed, digital library and information services are being implemented.

One of the key tasks for the university library is the task of forming users' digital competencies using digital forms and means of communication. Libraries can be encouraged to actively interact with the educational divisions of the university, faculty to be included in the information and educational environment of the university.

\section{References}

Abdrakhmanova, G.I., Baskakova, O.E., Vishnevsky, K.O., Gokhberg, L.M.and etc. (2020). Trends of Internet development in Russia and foreign countries: analytical report. National Internet Domain Focal Point, Higher School of Economics Publ.144 p. 
Abdrakhmanova, G.I., Baskakova, O.E., Vishnevsky, K.O., Gohberg, L.M. and etc. (2020). Trends in the development of the Internet in Russia and foreign countries: analytical report. Coordination center of the national domain of the Internet, Higher School of Economics Publ. $144 \mathrm{p}$.

Adeleke, A.A., Solanke, O.E., Oguntayo, S.A. (2019) The use of the library and lifelong learning in faith-based private universities in Nigeria. Bilgi Dunyasi. 20(1). 65-80.

Al-Madani, F.M. (2020). THE impact of quality content educational resources on students' academic achievement: Survey research (on the example of northern border university, arar). Obrazovanie i Nauka.22(5). 132-149.

Astakhova, L.V. (2019). Development of digital culture of students in the conditions of the university library. Bulletin of Culture and Arts. 4(60). 47-57.

Baker, J. Moore, C., Priego, E., Alegre, R., Cope, J., Price, L., Stephens, O., D. van Strien, Wilson, G. (2016). Library carpentry: Softwarem skills training for library professionals. LIBER Quarterly. 26(3). $141-162$.

Chalkiadaki, A. (2018). A systematic literature review of 21st century skills and competencies in primary education. International Journal of Instruction. 11(3). 1-16.

Cox, A.M., Kennan, M.A., Lyon, L., Pinfield, S., Sbaffi, L. (2019). Maturing research data services and the transformation of academic libraries. Journal of Documentation. 75(6). 1432-1462.

Dempsey, L. (2017). Library collections in the life of the user: Two directions. LIBER Quarterly. 26(4). 338-359.

Ducas, A., Michaud-Oystryk, N., Speare, M. (2020). Reinventing ourselves: New and emerging roles of academic librarians in Canadian research- intensive universities.College and Research Libraries. 81(1). 43.

Gendina, N.I. (2005). Information literacy or information culture: alternative or unity (results of Russian studies). School library. 3. 18-24.

Grant, R.C., Organ, M. (2020). Digital Journeys @ UOW Australia: From Digital Dexterities to Digital Humanities and Beyond.International Information and Library Review. pp. 1-6.

Green, H., Dickson, E. (2017). Expanding the Librarian's tech toolbox: The «Digging Deeper, Reaching Further: Librarians Empowering Users to Mine the HathiTrust Digital Library» project.D-Lib Magazine. 23(5-6). Accessed at: http://www.dlib.org/dlib/may17/green/05green.html

Hallo, M., Luján-Mora, S., Maté, A., Trujillo, J. (2016). Current state of Linked Data in digital libraries. Journal of Information Science. 42(2). 117-127.

Khan, R., Khan, A., Malik, S., Idrees, H. (2017). Virtual reference services through web search engines: Study of academic libraries in Pakistan. Publications. 5(2).

Kohnke, O. (2017). It's Not Just About Technology: The People Side of Digitization. Shaping the DigitalEnterprise. Springer, Cham. pp. 69-91.

Kudrina, E.L., Ivina, K.V. (2019). Digital environment - new challenges to the university library. Bulletin of Kemerovo State University. Series: Humanities and Social Sciences. 3(2). 126-134. DOI: 10.21603/2542-1840-2019-3-2-126-134.

Mikhailova, E.G., Shekhonin, A.A., Eliseeva, O.V., Egorova, O.B. (2019). «Digital Culture» at ITMO University Modern Education: content, technology, quality. Materials of the XXV International Scientific and Methodological Conference. Publishing House of St. Petersburg State Technical University «LETI,» $666 \mathrm{p}$.

Pontika, N. (2019). Roles and jobs in the open research scholarly communications environment: Analysing job descriptions to predict future trends.LIBER Quarterly. 29(1).

Praseptiawan, M., Siswanto, P., Afrida, T. (2019). Digital Library Development and Evaluation to Improve Students' Digital Literacy. Journal of Physics: Conference Series. 1179(1).

Raza, Z., Mahmood, K., Warraich, N.F. (2019). Application of linked data technologies in digital libraries: a review of literature.Library Hi Tech News. 36(3). 9-12.

Shen, Y. (2019). Emerging scenarios of data infrastructure and novel concepts of digital libraries in intelligent infrastructure for human-centred communities: A qualitative research. Journal of Information Science. 45(5). 691-704. 
Ruslan A. Baryshev, Elena N. Kasyanchuk... Formation of Digital Competences of University Library Users

Sinisalo, R. (2015) Customizing new library catalogue for information literacy, digital collections and sustainable development. Communications in Computer and Information Science. 552. 38-46.

Smolina, S.G. (2016). Development of the information competence of students in the conditions of the university library. Autoreferat dissertations for the degree of candidate of pedagogical sciences. ChelyabinskPubl.

Smolina, S.G., Legendchuk, M.V. (2019). Potential of the university library in the development of information competence. Scientific and technical libraries. 4. 17-27.

Soltovets, E., Chigisheva, O., Dmitrova, A., Soltovets, E. (2020). The role of mentoring in digital literacy development of doctoral students at British universities. Eurasia Journal of Mathematics, Science and Technology Education. 16(4).

Soria, K.M., Fransen, J., Nackerud, S. (2017) Beyond books: The extended academic benefits of library use for first-year

college students.College and Research Libraries. 78(1). 8-22.

Tulchinsky, G.L. (2017). Digital transformation of education: challenges to higher education. Philosophical sciences. 6. 121-136.

Vinogradova, T.S. (2012). Information competence: problems of interpretation. Man and education. 2 (31). 92-98.

Wadson, K. (2019). Collaborative and interactive teaching approaches have a positive impact on information literacy instruction supporting evidence based practice in work placements. Evidence Based Library and Information Practice. 14(1). 62-64.

Zaitseva, N. A. Larionova, A.A., Gornostaeva, Z.V., Malinina, O.Y., Povalayeva V. A., Vasenev, S.L., Skrynnikova, I.A., Ersozlu, A. (2017). Elaboration of the methodology for assessing the development of managerial competences in university students taught with the use of case-technologies. Eurasia Journal of Mathematics, Science and Technology Education. 13(11). 7339-7351.

Tabachuk, N.P. (2019). Information, digital and smart-competencies of the individual: transformation of views. Scientific and pedagogical review. (26). 133-141. 